\title{
PENETAPAN KADAR FENOLIK TOTAL DARI EKSTRAK ETANOL BUNGA ROSELLA (Hibiscus sabdariffa L.) BERWARNA UNGU MENGGUNAKAN SPEKTROFOTOMETRI UV-VIS
}

\author{
Andi Herlinda ${ }^{1}$, Abd. Malik ${ }^{2}$ dan Ahmad Najib ${ }^{3}$ \\ Fakultas Farmasi, Universitas Muslim Indonesia Makassar \\ 1andiherlinda@gmail.com
}

\begin{abstract}
One of the herb plants, purple Roselle flowers (Hibiscus sabdariffa L), used to traditionally for various diseases. The aim of this research is to determine the total phenolic content of ethanol extract of purple Roselle flowers. Sample as many one kilograms extracted by maceration method using ethanol 96\%. Resulty 120 grams thick extract. Total phenolic content determined by UV-Vis spectrophotometer at wave leght $743 \mathrm{~nm}$ with gallic acid as standard reference with Folin-Ciocalteau reagent. The result show the rendamen of ethanolic extract $12 \%$ with total phenolic content $1.6726 \%$.
\end{abstract}

Keywords: Total phenolic, extract ethanol of purple Roselle flowers (Hibiscus sabdariffa L), Folin-Ciocalteau method, UV-Vis spectrophotometer.

\section{PENDAHULUAN}

A. Latar Belakang

Tanaman sebagai bahan obat telah dimanfaatkan masyarakat Indonesia sejak dahulu, salah satu tanaman yan banyak digunakan sebagai bahan obat saat ini yaitu bunga rosella (Hibiscus sabdariffa L.) yang menjadi begitu popular, hal ini dikarenakan hampir seluruh bagian tanamannya dapat digunakan untuk kebutuhan pengobatan. Nilai gizi dan kandungan kimia dari rosella diantaranya adalah vitamin $\mathrm{C}$, vitamin $\mathrm{A}$, dan 18 jenis asam amino yang diperlukan tubuh, protein, karbohidrat, tiamin, kalsium, antosianin, niacin, flavonoid, alkaloid dan asam stearat. Antosianin, flavonoid, dan polyphenol merupakan zat kardioprotektif pencegah penyakit kardiovaskular yang terdapat dalam kelopak bunga rosella. Selain itu kelopak bunga rosella juga berfungsi untuk menurunkan kadar kolesterol darah, antikanker, peluruh air seni, merangsang keluarnya empedu dari hati, antihipertensi, antidiabetes, mengurangi kekentalan (viskositas) darah, antiskorbut (sariawan akut), mengurangi batuk, meningkatkan peristaltik usus serta terapi gangguan liver dan asam urat (Herti, 2005; Mahadevan et al.,2009).

Rosella (Hibiscus sabdariffa, L) adalah tanaman yang berasal dari Asia dan Afrika. Menurut penelitian yang dilakukan Hsieh dkk (2008) kelopak bunga Rosella memiliki aktivitas antioksidan dengan nilai IC50 $0,25 \mathrm{mg} / \mathrm{ml}$ (Ruangsri et al, 2008).

Rosella mengandung senyawa fenolik yaitu flavonoid (antosianin) pada kelopak bunganya. Mengingat pentingnya fungsi senyawa fenolik sebagai antioksidan untuk pencegahan dan pengobatan penyakit degeneratif, kanker, penuaan dini dan gangguan sistem imun tubuh, maka perlu dilakukan penelitian mengenai kadar fenolik total dalam kelopak bunga rosella ungu. Dengan demikian, usaha pemanfaatan tanaman rosella sebagai obat herbal dapat lebih maksimal karena dengan melihat kadar fenolik total maka besar aktivitas antioksidannya dapat diperkirakan (Apsari, 2011).

\section{METODE PENELITIAN}

\section{A. Pengambilan dan pengolahan sampel}

Tanaman Rosella (Hibiscus sabdariffa L.) yang digunakan berasal dari Lahan Gunung Pohsarung, Kecamatan Semen, Kabupaten Kediri (Jawa Timur). Sampel yang digunakan yaitu ekstrak etanol bunga Rosella (Hibiscus sabdariffa L.) berwarna ungu.

\section{B. Pengolahan Sampel}

Bunga rosella (Hibiscus sabdariffa L.) berwarna ungu yang telah dikeringkan selanjutnya dibuat serbuk lalu siap diekstraksi.

\section{Metode Ekstraksi}

Serbuk bunga rosella kelopak berwarna ungu bunga Ditimbang $1 \mathrm{~kg}$ bunga rosella (Hibiscus sabdariffa L.) ungu, kemudian dimasukan serbuk bunga rosella (Hibiscus sabdariffa L.) ungu yang akan disari kedalam bejana maserasi. Dituang secara perlahan pelarut etanol $96 \%$ kedalam bejana maserasi yang berisi serbuk bunga rosella ungu. Kemudian biarkan cairan penyari merendam serbuk simplisia selama selama 3x24 jam, kemudian disaring dan dilakukan remaserasi dengan pelarut yang sama 
sampai jernih. Proses ekstraksi ini dapat dihentikan apabila warna ampas serbuk telah berubah menjadi lebih pucat atau maserat berwarna lebih bening. Hasil penyarian dari ekstrak diuapkan dengan menggunakan rotavapor dibawah titik didih hingga diperoleh ekstrak kental dan untuk menghilangkan keberadaan jejak- jejak sisa air.

\section{Penetapan Kadar Fenolik Total \\ a. Pembuatan Larutan baku}

Pembuatan larutan standar asam gallat dilakukan dengan melarutkan $10 \mathrm{mg}$ asam galat kedalam etanol $96 \%$ menggunakan labu takar $10 \mathrm{~mL}$ hinggam menghasilkan konsentrasi 1000 ppm. Dari larutan stock dipipet sebanyak $0,25 \mathrm{~mL}$ diencerkan dengan etanol $96 \%$ hingga volume $25 \mathrm{~mL}$ hingga dihasilkan konsentrasi $10 \mathrm{ppm}$. Dari larutan tersebut dipipet 1, 2, 3, 4 dan $5 \mathrm{~mL}$ dan dicukupkan dengan etanol $96 \%$ hingga $10 \mathrm{~mL}$, sehingga dihasilkan konsentrasi 1, 2, 3, 4 dan 5 ppm. untuk pembuatan kurva baku masing-masing tabung reaksi. Selanjutnya untuk masing-masing larutan standar tersebut ditambahkan dengan 0,4 mL reagen Folin- Ciocalteau dan diinkubasi selama 4-8 menit. Kemudian larutan ditambahkan dengan 4,0 $\mathrm{mL} \mathrm{Na}_{2} \mathrm{CO}_{3} 7 \%$, lalu ditambahkan dengan aquadest steril sampai batas tanda. Setelah 2 jam inkubasi, absorbansi larutan diukur pada panjang gelombang $743 \mathrm{~nm}$ dengan larutan blanko air suling dan reagen Folin-Ciocalteau.

\section{b. Pengukuran Kadar Fenolik Total dari Bunga Rosella Berwarna Ungu}

Penetapan kadar pada ekstrak etanol bunga rosella (Hibiscus sabdariffa L.) ungu merujuk pada prosedur Chun et al (2003) dengan beberapa modifikasi yaitu sampel ekstrak etanol bunga rosella (Hibiscus sabdariffa L.) ungu dibuat dengan cara menimbang $10 \mathrm{mg}$ kemudian dilarutkan dengan 10 $\mathrm{mL}$ etanol $96 \%$ dan dihomogenisasi. Dipipet sebanyak $1 \mathrm{~mL}$ kemudian dicukupkan dengan 10 $\mathrm{ml}$ etanol $96 \%$. Selanjutnya dipipet $1 \mathrm{ml}$ dari larutan tersebut untuk tiga replikasi. Masingmasing larutan ditambahkan dengan $0,4 \mathrm{~mL}$ reagen Folin-Ciocalteau dikocok dan dibiarkan 4-8 menit, tambahkan 4,0 mL larutan $\mathrm{Na}_{2} \mathrm{CO}_{3} 7 \%$ kocok hingga homogen. Tambahkan aquadest steril hingga $10 \mathrm{~mL}$ dan diamkan selama 2 jam pada suhu ruangan. Ukur serapan pada panjang gelombang serapan maksimum $743 \mathrm{~nm}$ yang akan memberikan kompleks biru. Lakukan 3 kali pengulangan sehingga kadar fenol yang diperoleh hasilnya didapat sebagai mg ekuivalen asam galat/100 mg sampel segar. Nilai fenolik total dinyatakan dalam Gallic Acid Equivalents (GAE) tiap $100 \mathrm{~g}$ berat kering ekstrak etanol bunga rosella ungu $\mathrm{g}$ GAE/100 $\mathrm{g}$ berat kering ekstrak etanol rosella ungu.

\section{HASIL DAN PEMBAHASAN}

Bobot ekstrak etanol bunga rosella ungu yang diperoleh yaitu 120 gram. Sedangkan persen rendamen pada ekstrak etanol Rosella ungu 12\%. Hasil pemeriksaan secara kualitatif dengan menggunakan KLT membuktikan bahwa kelopak bunga Rosella mengandung fenolik.

Tabel 1. Hasil Uji Kualitatif Adanya Senyawa Fenolik ekstrak etanol bunga Rosella (Hibiscus sabdariffa $\mathrm{L}$.) ungu

\begin{tabular}{ccc}
\hline \multirow{2}{*}{ Sampel } & Uji fenolik & Hasil pengamatan \\
\cline { 2 - 2 } & $\mathrm{FeCl}_{3}$ & (Flavonoid) \\
\hline $\begin{array}{c}\text { Kelopak } \\
\text { Ungu }\end{array}$ & $\begin{array}{c}\text { Biru } \\
\text { Kehitaman }\end{array}$ & $(+)$ \\
\hline
\end{tabular}

Keterangan :

$(+)=$ menunjukkan adanya flavonoid

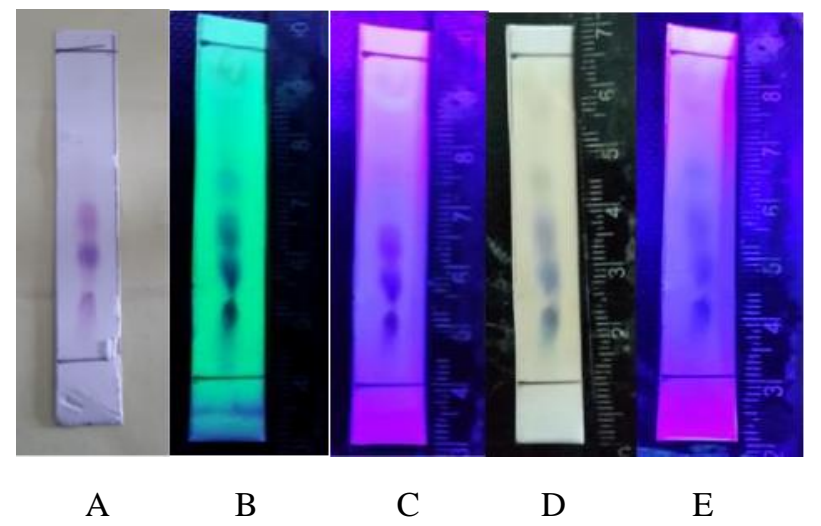

Gambar 1. Profil KLT Ekstrak Etanol Bunga Rosella (Hibiscus sabdariffa L.) Berwarna Ungu

\section{Keterangan :}

Fase diam : Silica gel $60 \mathrm{~F}_{254}$

Fase gerak : n-nutanol:Asam asetat:Aquadest (4:1:5)

(A) Sinar tampak

(B) $\mathrm{UV}_{254} \mathrm{~nm}$

(C) $\mathrm{UV}_{366} \mathrm{~nm}$

(D) Penyemprotan $\mathrm{FeCl}_{3}$

(E) Penyemprotan $\mathrm{FeCl}_{3} \mathrm{UV}_{366} \mathrm{~nm}$

Analisis metode penetapan kadar fenolik dengan menggunakan metode Folin-Ciocalteau cara Chun et al. (2003), dan sebagai standar digunakan larutan asam galat atau asam 3,4,5trihidroksibenzoat $\left(\mathrm{C}_{6} \mathrm{H}_{2}(\mathrm{OH})_{3} \mathrm{CO}_{2} \mathrm{H}\right)$ (Apsari dan Susanti, 2011). Asam galat murni berbentuk bubuk organik Kristal tak berwarna dan merupakan molekul bebas atau bagian dari molekul tanin. Asam galat 
mempunyai sifat antifungal, antiokasidan, dan antiviral (Nely dan Fardiaz, 2007).

Untuk menetukan anilis fenolik total, terlebih dahulu dilakukan scanning dari panjang gelombang 400-800 nm. Diperoleh panjang gelombang maksimal $473 \mathrm{~nm}$ sesuai dengan metode Chun et al (2003). Selanjutnya dilakukan pengukuran absorbansi pada larutan standar asam galat yang akan digunakan sebagai pembanding.

Tabel 2. Hasil Penetapan Kadar Fenolik Total Bunga Rosella Berwarna Ungu

\begin{tabular}{ccc}
\hline Sampel & $\begin{array}{c}\text { Rata-rata kandungan } \\
\text { fenolik total (mg } \\
\text { GAE/100 g }\end{array}$ & $\begin{array}{c}\text { \% Kadar } \\
\text { Fenolik }\end{array}$ \\
\hline $\begin{array}{c}\text { Bunga } \\
\text { Rosella } \\
\text { Ungu }\end{array}$ & 16,7265 & 1,6726 \\
\hline
\end{tabular}

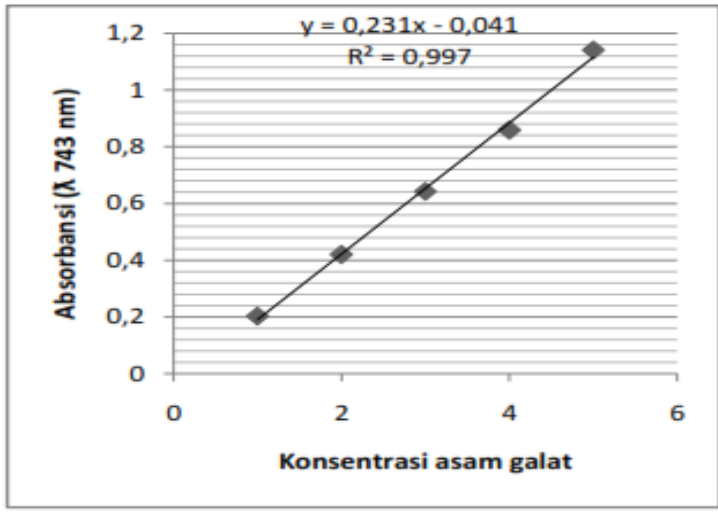

Gambar 2. Kurva kalibrasi asam galat pada panjang gelombang $743 \mathrm{~nm}$

Pengukuran absorbansi dilakukan menggunakan spektrofotometri UV-Vis dengan serapan maksimum $473 \mathrm{~nm}$. Warna yang dihasilkan dari larutan standar asam galat adalah kuning. Semakin tinggi konsentrasi yang digunakan, semakin pekat warna kuning yang dihasilkan. Hasil Pengukuran absorbansi larutan standar asam galat diperoleh dimasukan kedalam Microsoft excel untuk mendapatkan kurva kalibrasi larutan 4standar asam galat berupa grafik kurva konsentrasi (C) versus absorbansi (A) dan dapat ditunjukan pada gambar 2 . Berdasarkan Gambar dapat dilihat bahwa kurva kalibrasi dengan persamaan regresi untuk untuk absorbansi asam galat sebesar $\mathrm{y}=0,2312 \mathrm{x}-0,041$; larutan standar senyawa fenolik diperoleh hubungan yang linier antara absorbansi dengan konsentrasi. Pada pengukuran absorbansi yang ditunjukkan dengan nilai koefisien korelasi (r) sebesar 0.9971. nilai (r) yang mendekati 1 menunjukkan bahwa persamaan regresi adalah linear.
Kandungan penting yang terdapat pada kelopak bunga rosela adalah pigmen antosianin yang merupakan golongan flavonoid yang berperan sebagai antioksidan (Mardiah et al, 2009).

Adapun hasil yang diperoleh dari kadar fenolik total ekstrak etanol bunga Rosella ungu, $16,7265 \mathrm{mg} \mathrm{RE} / \mathrm{g}$ ekstrak atau $1,6726 \%$. Senyawa fenol yang terkandung dalam ekstrak etanol bunga Rosella (Hibiscus sabdariffa L.) berwarna ungu merupakan hasil metabolit sekunder yang potensial sebagai sumber bahan baku obat.

\section{KESIMPULAN}

Dari hasil penelitian dapat disimpulkan bahwa kadar ekstrak etanol bunga rosella ungu memiliki kandungan fenolik dengan kadar fenolik total sebesar $16,7265 \mathrm{mg}$ GAE/g ekstrak dengan persentase kadar fenol total (b/b) sebesar 1,6726\%.

\section{DAFTAR PUSTAKA}

Apsari, P.D., \& Susanti, H. 2011. Perbandingan Kadar Fenolik Total Ekstrak Metanol Kelopak Merah dan Ungu Bunga Rosella (Hibiscus sabdariffa, Linn) Secara Spektrofotometri. ISBN: 978-979-18458-47.

Ariati, R., Arifin, H., \& Muchtar, H. 2012. Pengaruh Fraksi Air Kelopak Bunga Rosella (Hibiscus sabdariffa. L) Terhadap Kadar Kolesterol Darah Tikus Putih Jantan Hiperkolesterol dan Hiperkolesterol Disfungsi Hati. Artikel. Universitas Andalas.

Departemen Kesehatan Republik Indonesia. 2000. Penelitian Tanaman Obat Dibeberapa Perguruan Tinggi Indonesia Edisi $X$. Jakarta: Percetakan Negara.

Direktorat Jendral Pengawasan Obat dan Makanan. 2000. Parameter Standar Umum Ekstrak Tumbuhan Obat. Jakarta : Departemen Kesehatan Republik Indonesia.

Chun, O.K., Kim, D.O., and Lee, C.Y., 2003, Superoxide Radical Scavenging Activity of The Major.

Polyphenols in Fresh Plums, J. Agric. Food Chem, 51, 8067-8072.

Fessenden. J, et al. 1986. Kimia Organik Edisi III. Glora Aksara Pratama. Jakarta. 
Harborne. (1996). Metode Fitokimia: Penuntun Cara Modern Menganalisa Tumbuhan. Bandung: ITB.

Harbone, J.R., (1987). Metode Fitokimia Penuntun Cara Modern Mengekstraksi Tumbuhan. Terjemahan Padmawinata Edisi kedua ITB. Bandung.

Harmanto, N. 2007. Herbal Untuk Keluarga Jus Herbal Segar dan Menyehatkan. Jakarta: PT Elex Media Komputindo.

Harmita. 2006. Petunjuk pelaksanaan Validasi Metode dan Cara Perhitungannya. FMIPA. Universitas Indonesia. Depok.

Herty, M dan Kristiana, L. 2005, Khasiat dan Manfaat Rosela. Cetakan I, Agromedia Pustaka. Jakarta.

Huang, D., Ou, B., and Prior, R.L., 2005, The Chemistry behind Antioxidant Capacity Assays, Journal of Agricultural and Food Chemistry, 53, 1841.

Khopkar. 1990. Konsep Dasar Kimia Analitik. Universitas Indonesia. Jakarta.

Laurence, J.D. 12 Juli 2013. Hibiscus sabdariffa. 17 September 2013: http://www.itis.gov/servlet/SingleRpt/Single Rpt?search_topic $=T S N \&$ search_value $=5030$ $\underline{01}$.

Lee, K.I., Kim, Y.J., and Lee, C.H. 2003. Cocoa Has Mora Phenolic Phytochemical and Hiher Antioksidant Capacity than Teas and Red Wine. J. Agric. Food Chem., 51 : 7292-7295.

Mahadevan, N., Shivali and Kamboj, V. 2009. Hibiscus sabdariffa Linn. - An overview. Natural product radiance, Vol. 8(1), 2009, pp. 77-83.

Mardiah, et al. 2009. Budidaya dan Pengolahan Rosella. Ed. Ke-1. Jakarta. Agromedia.

Markham, K. R. 1988. Cara Mengidentifikasi Flavanoid. Terjemahan Kosasih Padmawinata, Penerbit ITB : Bandung.

Maryani, H., Kristiana, L. 2008. Khasiat dan Manfaat Rosela. Jakarta. PT Agro Media Pustaka. hal 6, 25-31.
Mulja, M, dan Suharman. 1995. Spektrofotometri UVVis. Analisis Instrumental (pp. 26,28-30). Surabaya : Airlangga University Press.

Nely dan Fardiaz. 2007. Aktivitas Antioksidan Rempah Pasar dan Bubuk Rempah Pabrik dengan Metode Polifenol dan Uji AOM (Active Oxygen Method). Institute Tehnologi Bandung : Bandung.

Ruangsri, P., Chumsri, P., Sirichote, A., dan Itharat, A., 2008, Changes in Quality and Bioactive Properties of Concentrated Roselle (Hibiscus sabdariffa Linn.) Extract, As. J. Food AgInd,1(02), Hal 62-67.

Rostinawati, T., 2009. Aktivitas Antibakteri Ekstrak Etanol Bunga Rosella (Hibiscus sabdariffa L.) Terhadap Escherichia coli, Salmonella typii dan Staphylococcus aureus Dengan Metode Difusi Agar. (Skripsi). Jatinangor : Universitas Padjadjaran.

Seafast. 2 Maret 2012. Senyawa Fenolik pada Sayuran Indigenous. 21 September 2013 : http://seafast.ipb.ac.id/ tpc- project/ wpcontent/uploads/2012/03/1-senyawafenolik.pdf

Seafast. 2012. Biosintesis Senyawa Fenolik. 21 September 2013. seafast.ipb.ac.idtpcprojectwp. 2-biosintesis.pdf.

Silvi,2008 Special Preblem With The Extraction of Plant. Human Press : Totowa, New Jersey.

Steenis. V, et al. 2005. Flora. PT. Pradnya Paramita, Jakarta.

Sukesi dan Sirat, D.W. 2012. Antioksidan dalam Baksos Rumput Laut Merah Eucheuma Cottonii. Jurnal Sains dan Seni Pomits Vol. 1, No. 1: 1-4.

Soekamto, M.A. Pengaruh Pemberian Seduhan Kelopak Kering Bunga Rosella (Hibiscus sabdariffa) Terhadap kadar Trigliserida Serum Tikus Sprague-Dawley Hiperkolestrolemik. Karya Tulis Ilmiah

Sudjadi. 2007. Kimia Farmasi Analisis. PT. Pustaka Pelajar. Jakarta.

Tanjong, A. 2011. Pengaruh Konsentrasi Ekstrak Kelopak Bunga Rosella (Hibiscus sabdariffa L.) Terhadap Koloni Candida 
Albicans yang Terdapat pada Plat Gigitiruan. (Skripsi). Makassar: Universitas Hasanuddin.

Ukieyana, E., (2012). Aktivitas Antioksidan, Kadar Fenolik Dan Flavanoid total Tumbuhan Suruhan (Peperomia pellucid L. Kunth). Fakultas Teknologi Pertanian Institut Pertanian Bogor. Bogor

Voigt R. 1994. Buku Pelajaran Teknologi Farmasi. Penerjemah Dr. Soendani Noerono. Edisi Kelima. Yogyakarta: Gadjah Mada University Press. 